LINGUA, Vol. 16, No. 1, Maret 2019

p ISSN: 1979 9411; e ISSN: 2442 238X

Http://lingua.pusatbahasa.or.id; Email: presslingua@gmail.com

Center of Language and Cultural Studies, Surakarta, Indonesia

Guswita, Ade Khairani. 2019. Presupposition Triggers in the Washington Post and

Lost Angeles Times Online News. Lingua (2019), 16(1): 25 36. DOI: 10.30957/lingua.v16i1.572.

\title{
PRESUPPOSITION TRIGGERS IN THE WASHINGTON POST AND LOST ANGELES TIMES ONLINE NEWS
}

\author{
Khairani Ade Guswita ${ }^{1}$ \& Pratomo Widodo ${ }^{2}$ \\ Master Program in Applied Linguistics, Universitas Negeri Yogyakarta \\ Jl. Colombo No.1 Karang Malang, Yogyakarta \\ Corresponding author: khairaniadeguswitalubis@gmail.com
}

\begin{abstract}
The aim of this study is to analyze the use of presupposition triggers in the Washington Post and Los Angeles Times online news. This study was conducted by using qualitative approach. The sources of this study are the Washington Post and Lost Angeles Times news on the internet. The data were analyzed based on the theory about presupposition triggers from Levinson (1983) and Yule (1996). The data collection method in this study are Metode Simak and Metode Catat which are proposed by Sudaryanto (2018). The result of this study is the most dominant types of triggers presuppositions which found in the Washington Post online news is definite description with 29 occurrences (26\%) and 37 occurrences (24\%)in Lost Angeles online news. Both the Washington Post and Los Angeles Times online news use the clef-construction as part of lexical and non-restrictive clause as part of structural which more dominant than others. Otherwise, the distinction on two online is conventional times which only appeared in Los Angeles Times.
\end{abstract}

Keywords: presupposition, presupposition triggers, news, Washington Post, Los AngelesTimes

DOI: 10.30957/lingua.v16i1.572.

\section{INTRODUCTION}

As social beings, language is used by people to communicate with others from different culture background. Everyone needs language to interact with other people. Without language, people can't convey feeling, thought, intention, and information. Language is used to express their views and opinions toward something in form of spoken or written. The use of language as a communication tool can be found in the delivery of news. In nowadays, news is not only available in printed form such as newspaper or magazine, but also electronic form especially on the internet. Internet usage grows rapidly around the world. Everyone can access and get information quickly whenever and wherever they want to know what happened today. It makes that many news sites provide information about national and international events. As a part of the news, there are writers or journalists who make the news and give the reader a lot of information from their comment, point of view or opinion about the recent issues. 
LINGUA, Vol. 16, No. 1, Maret 2019

p ISSN: 1979 9411; e ISSN: 2442 238X

Http://lingua.pusatbahasa.or.id; Email: presslingua@gmail.com

Center of Language and Cultural Studies, Surakarta, Indonesia

Guswita, Ade Khairani. 2019. Presupposition Triggers in the Washington Post and

Lost Angeles Times Online News. Lingua (2019), 16(1): 25 36. DOI: 10.30957/lingua.v16i1.572.

Journalists provide information to influence the reader's opinion through their languages which are used in the news. As Zare', Abbaspour \& Nia (2012) state that the languages used in mass media play an important role by the journalists of media attempt to consciously or unconsciously influence the reader understanding the content of the news. This means the journalists try to get trust through the information which they have given with the values of their opinions both negative and positive values. Thus opinions are related to the presence of presupposition.

In linguistic, presupposition is one of the branch of pragmatic study. Liang \& Liu (2016) state that presupposition as a part of the common ground which embedded in an utterance which is taken for granted by speaker \& listener, or writer \& reader. In addition, Yule (2006) states that a presupposition is something that the speaker or reader assumes to be the case prior to make a sentence or utterance. In other words, the assumption of speaker or writer is already believed as truthful by the addressee. The speaker or writer should know or assume about presupposition so that the context of the utterance or sentence can be understood. The study of presupposition still continues until now and it has been found that use of lexical items or linguistic constructions is typically generated by presuppositions, which is called presupposition triggers (Levinson, 1983; Huang, 2007). This trigger is realized as a projection of the meaning which is assumed in the sentence. It makes the reader take the existence of referent on trust (Grundy, 2000:120).

Presupposition triggers are related to the linguistic items that trigger the presupposition. Levinson (1983:179) states that the term 'trigger' as presupposition generating linguistic item. This means that a linguistic item that can refer to presuppose a meaning in a sentence is known as presupposition triggers. Since news is articles written by the journalist or editors, it implies that the implied meaning that they presuppose can be easily marked by its triggers.

Therefore, this study concerns with pragmatic studies which is aimed to analyze and find out the type of presupposition triggers which are used by journalists from two online website news, they are the Washington Post and Lost Angeles Times Online News. The Washington Post also known as WaPo is a major American daily newspaper published in Washington, D.C. but it is also available electronic form. This online website news is a particular emphasis on national politics and the federal government. The Los Angeles Times also known as L.A. Times is a daily newspaper which has been published in Los Angeles, California and also available electronic form. L.A Times is known for its coverage of issues particularly salient to the U.S. west coast, such as immigration trends, natural disasters, and also politic issues. Therefore, the writer focuses on political issues because in nowadays mass media such as online news do not only became the power of controlling authority but also become a political force. So that the journalist or writers provide the information to influence the reader with their point of view and try to make the reader believe what they have written in the news especially in political news.

The topic of the trigger for this presupposition is chosen because of some reasons, namely for the reader and the writer. Readers get informed that the journalists try consciously or unconsciously to influence the readers' understanding about particular 
LINGUA, Vol. 16, No. 1, Maret 2019

p ISSN: 1979 9411; e ISSN: 2442 238X

Http://lingua.pusatbahasa.or.id; Email: presslingua@gmail.com

Center of Language and Cultural Studies, Surakarta, Indonesia

Guswita, Ade Khairani. 2019. Presupposition Triggers in the Washington Post and

Lost Angeles Times Online News. Lingua (2019), 16(1): 25 36. DOI: 10.30957/lingua.v16i1.572.

issues. Bekalu (2011:2) states that news try to achieve the cognitive effects needed for the reader and to obscure certain issues through using of unfair presupposition. In other words, the reader is expected to be able to understand the information in the news and get an idea of what the writer wants to say. For news writers are to understand assumptions to help them make statements which are easily understood by readers. Journalists or writers should make sentences that assumptions are known by the reader. It is aimed to avoid misinterpretation between the writer and the reader. In other words, by using the trigger of presupposition, journalist or writers try to influence the reader's opinion of issues or event. Therefore, this present study needs to be done in this paper. It aims to find out the type of triggers presupposition in the Washington Post and Lost Angeles Times online news website. The writer found the use of trigger presuppositions in political news from both online website news.

\section{METHODS}

The study was conducted by using a qualitative approach. A qualitative is an inquiry useful approach for exploring and understanding a central phenomenon (Cresswell, 2002:16). In qualitative research method, the data taken from many texts are explored and analyzed using descriptive qualitative method since it intends to identify clauses, sentences and interpreted into the form of words rather than number. The data of this study are phrases and clauses of presupposition triggers in two online news website. The sources of this study are the Washington Post and Lost Angeles Times news on the internet. The selection of that online news was because both of them particularly emphasized on national politics and the federal government issues. The data collection method was Metode Simak and Metode Catat which are proposed by Sudaryanto (2018). Collecting data begins by picking out three news of each Washington Post and Lost Angeles Times News. This could be done by searching politic column in its official website of the Washington Post and Lost Angeles Times News. After that, news was selected as the need for this study. Then, finally, sentences in news were listed and where clauses or phrases were analyzed based on the theory about presupposition triggers from Levinson (1983) and Yule (1996).

There are three type of presupposition triggers. They are existential (definite descriptions); lexical (implicative and factive verbs, change of sate verbs and verbs of judging, counter factual verbs, conventional items and iterative); and structural (cleft constructions, Wh-questions, adverbial and comparative construction, and counter factual conditionals, and non-restrictive clauses). The data analysis method used in this study is Metode Padan. It is a method of analyzing data which determines the outside, regardless, and does not become part of the language concerned or researched (Sudaryanto, 2018). The findings of the research were finally reported by the writer.

\section{RESULTS AND DISCUSSION}

Based on the data obtained from six news of the Washington Post and Lost Angeles Times News, there are 235 sentences selected from the six news articles. These sentences were analyzed and as result there are 264 occurrences which identified by using presupposition triggers proposed by Levinson (1983) and Yule (1996) namely 
LINGUA, Vol. 16, No. 1, Maret 2019

p ISSN: 1979 9411; e ISSN: 2442 238X

Http://lingua.pusatbahasa.or.id; Email:presslingua@gmail.com

Center of Language and Cultural Studies, Surakarta, Indonesia

Guswita, Ade Khairani. 2019. Presupposition Triggers in the Washington Post and

Lost Angeles Times Online News. Lingua (2019), 16(1): 25 36. DOI: 10.30957/lingua.v16i1.572.

definite description, factive verb, implicative verb, change of state verbs, verbs of judging, conventional items, iterative, cleft construction, wh-questions, adverbial clause, comparative constructions, counterfactual conditional sentence and nonrestrictive relative clause. Note that L.A. Times stands for Los Angeles Times and Washington Post stands for WaPo and the mark ' $>>$ ' sign the presupposed meaning of the italic lexical, phrasal or structural form. The following data represent the presupposition triggers in the Washington Post and Lost Angeles Times News.

\subsection{Existential Presupposition Triggers (Definite Description)}

The linguistic constructions that are associated with a presupposition of existence are referred as existential presupposition. The linguistic constructions such as possessive constructions and more generally definite noun phrase can give rise to presupposition (Yule, 1996). In other word, a presupposition of existence is given rise by the possessive constructions in English, moreover the existential presupposition is assumed to be present more generally in any name or definite noun phrase, and also definite description, in which the addresser is assumed to be committed to the existence of the entities name.

John Sides, a George Washington University political scientist, was still blunter. (LA Times: Oct'18)

>> There exists a man called John Sides who is the George Washington University political scientist.

The example above indicates the noun phrase John Side occurred as presupposed that there exists a man called John Side who is a George Washington University political scientist. This means the existence of that person was available and was newly installed become a George Washington University political scientist.

\subsection{Lexical Presupposition Triggers}

Yule (1996) states that the use of some forms in lexical presupposition with their stated meanings is interpreted as the presentation of some non-asserted meanings. Type of lexical items trigger a presupposition as identified in the items as follows.

\subsubsection{Implicative Verbs}

Yule (1996) explains lexical presupposition is the condition of being implied or implied meaning to say someone to do something that contains the presupposed meaning and the asserted meaning. Therefore, tell someone did not manage to do something, the presupposed meaning (non-asserted) is that the person tried to do that something whereas the asserted meaning is that the person did not succeed. So the word 'managed' is interpreted as asserting 'succeeded' and presupposing 'tried.

In September, he (Feinstein) released a campaign video that attempted to link decades-old statements that Feinstein made about immigration with current 
LINGUA, Vol. 16, No. 1, Maret 2019

p ISSN: 1979 9411; e ISSN: 2442 238X

Http://lingua.pusatbahasa.or.id; Email:presslingua@gmail.com

Center of Language and Cultural Studies, Surakarta, Indonesia

Guswita, Ade Khairani. 2019. Presupposition Triggers in the Washington Post and

Lost Angeles Times Online News. Lingua (2019), 16(1): 25 36. DOI: 10.30957/lingua.v16i1.572.

statements from President Trump. (LA Times:Oct'18)

$>>$ Feinstein released a campaign video that try to link decades-old statements.

The journalist states he (Feinstein) released a campaign video that attempted to link decades-old statements shows. It shows that the use of verb attempt to triggers that something tried to do. It presupposes that De León as one of politician in America try to link decades-old statements with releasing a campaign video.

\subsubsection{Factive Verb}

The term 'factive' is used to classify of verb referring to referring to a verb which takes a complement clause and where the addresser presupposes the truth of the proposition expressed through the clause (Khaleel, 2010). In other words, the factive verbs reflect the factual state of a condition such as the words know, realize, appropriate, saw, focused to, agree, make sense, amuse, and etc.

She (De León) hasn't realized the rules of the game have changed dramatically in Washington with this new president. (LA Times:Oct'18)

>> The rules of the game have changed dramatically in Washington with this new president

The existences of verb realized in example above showed the presence of factive verbs presuppose the truth. The truth is the rules of the game have been changed dramatically by new president in Washington.

\subsubsection{Change of State Verbs}

Khaleel (2010) states change of state verbs presupposes that something has been in certain place or state before and involve the shift of a kind of behavior. Verbs in this category include start, stop, begin, continue, finish, go, arrive, change, leave, enter, take, etc.

Feinstein has continued to lead De León in the polls, but the double-digit margin she holds has shrunk since July, when she led by 22 points, according to surveys by the nonpartisan Public Policy Institute of California. (LA Times:Oct'18)

>>Feinstein leads De León in the polls, but the double-digit margin she holds has shrunk since July, when she led by 22 points

From the sentence above, the verb of continued is categorized into change of state verbs. The journalist use the word continue to trigger the presupposition that the polls is leaded by Freinstein. Their polls absolutely continue to lead each other. 
LINGUA, Vol. 16, No. 1, Maret 2019

p ISSN: 1979 9411; e ISSN: 2442 238X

Http://lingua.pusatbahasa.or.id; Email:presslingua@gmail.com

Center of Language and Cultural Studies, Surakarta, Indonesia

Guswita, Ade Khairani. 2019. Presupposition Triggers in the Washington Post and

Lost Angeles Times Online News. Lingua (2019), 16(1): 25 36. DOI: 10.30957/lingua.v16i1.572.

\subsubsection{Verb of Judging}

This type of trigger presupposition is not attributed to the speaker so much as to the subject of the verb of judging and it's unlike other presupposition (Levinson, 1983). In other word, verb of judging contains opinion or someone's point of view.

Former FBI director, James B. Comey accused President Trump on Monday of trying to burn down the entire FBI and charged that congressional Republicans were willing accomplices for failing to challenge him (WaPo: Dec'18)

$>>$ James B. Comey thinks President Trump on Monday of trying to burn down the entire FBI

The example above shows that the journalist use the word 'accused' because the journalist has opinion that former FBI director accused President Trump try to burn down the entire FBI. That sentence presuppose that James B. Comey thinks President Trump try to burn down the entire FBI on Monday.

\subsubsection{Conventional Items}

Levinson (1983) states that presuppositions of sentences can be seen as part of the conventional meaning of expressions which tied to lexical items.

Former first lady Michelle Obama has spent much of the past month touring the United States and sharing just how difficult it was not just being the president's wife but also enduring a campaign and perhaps more specifically, the current president's past role in making her life in the White House challenging (LA Times: Oct'18)

>>Barack Obama is married to Michelle Obama.

The sentence above shows that the occurrence of noun phrase president's wife triggered presupposition. The sentence presupposed Barack Obama is married to Michelle Obama who have a husband as a The President of America some years ago.

\subsubsection{Iterative Items}

Liang \& Liu (2016) defines iterative items as adverbs or verbs which presuppose previous existence of certain action or state. It refers to an event which takes pace repeatedly.

Lynch to declare the Clinton probe closed and then informing congressional leaders days before the 2016 election that it had been reopened (WaPo: Des'18)

>> Lynch to declare the Clinton probe had been opened

The sentence above shows the use of prefix re- in reopened. The occurrences of 
LINGUA, Vol. 16, No. 1, Maret 2019

p ISSN: 1979 9411; e ISSN: 2442 238X

Http://lingua.pusatbahasa.or.id; Email:presslingua@gmail.com

Center of Language and Cultural Studies, Surakarta, Indonesia

Guswita, Ade Khairani. 2019. Presupposition Triggers in the Washington Post and

Lost Angeles Times Online News. Lingua (2019), 16(1): 25 36. DOI: 10.30957/lingua.v16i1.572.

the writer that the incidents happened before, even it was still in progress until now or it had already been done. The aim of journalist use word reopened is to emphasize that the Clinton probe has closed but now from the Lynch declaration's that informing congressional leader days before the 2016 election, the Clinton probe still in investigation.

\subsection{Structural Presupposition Triggers}

A type of structural presuppositions is formed when certain sentence structures conventionally and regularly, presuppose that part of the structure is already assumed to be true. Addressers can use such structures to treat information as presupposed (i.e., assumed to be true), and, hence, to be accepted as true by the addressee.

\subsubsection{Clef Constructions}

The cleft construction consists of a clause 'wh-word' and usually what, a form of verb to be, and focused element such as a noun phrase, an infinitive clause, or a finite nominal clause (Khaleel, 2010).

A transcript of the first session suggested that Comey's first closed-door testimony mirrored much of what he has said in public settings (WaPo: Des'18)

>>Comey's first closed-door testimony mirrored much of something that he (Comey) convey in public settings.

From the sentence above, the occurrence what following finite nominal clauses triggered presupposition. The sentence above presupposed a transcript of the first session suggested that Comey's first closed-door testimony mirrored much of something that Comey have told before.

\subsubsection{Wh-Questions}

(Yule, 1996) state that the wh-question constructions in English are conventionally interpreted with the presupposition that the information after the wh-form as is already known to be true. This type of presupposition can lead addressers to believe that the information presented is necessarily true, rather than just the presupposition of the person asking the question.

What if someone with an unstable mind loaded a gun and drove to Washington? (WaPo : Des'18)

>>Someone with an unstable mind loaded a gun and drove to Washington.

Based on the sentence above, the sentence obtained the meaning that what happened if there is someone who have unstable mind loaded a gun and drove to Washington. The situation was scary. So, the using of question word "what" presuppose that the speaker is not happy with President Trump's loud and reckless innuendos that 
can putting his/her family's safety at risk.

\subsubsection{Adverbial Clauses}

Khaleel (2010) points out that adverbial clauses are used in the main clause which commonly placed either in initial or final position. In other word, the adverbial clauses isrelated to expression of time which usually placed either in initial or final position.

The rally came a day after Obama's blistering attack on Trump in an illinois speech outlining his rationale for a Democratic takeover of the House (LA: Sept'18)

>>Obama's blistering attacked on Trump in an Illinois speech outlining his rationale for a Democratic takeover of the House

The sentence above use of adverbial clauses as the complement sentence. The writer use conjunction "after" to determine the extra information that is delivered to the reader. The sentence above presupposes that Obama's blistering attacked on Trump in an illinois speech causes of the rally came a day.

\subsubsection{Comparative Constructions}

The use of comparisons and contrasts triggers presupposition. Thus, the comparative constructions (Adjective-er + than) and (As + adjective + as) signal the occurrence of a presupposition (Levinson, 1983).

Sides calculates that Trump's approval rating would be about $20 \%$ higher than it is today if not for his behavior, temperament and myriad scandals. (LA: Oct'18)

> Sides calculates that Trump's approval rating would be about $20 \%$

Based on the sentence above, the comparison marker higher than to presuppose that the Trump's approval rating about $20 \%$ and still count over if the President can control his behavior, temperament, and myriad scandal. The journalist use this presupposition triggers to express his deep concern toward his point of view to influence the reader.

\subsubsection{Counter Factual Conditionals}

Counter Factual Conditionals is the type of trigger presupposition, in which what is presupposed is not only true, but is the opposite of what is true, or contrary to facts (Yule, 1996:29).

In between the two interviews with House panels, Comey said at an event in New York that if Trump were not president, he would be in serious jeopardy of being charged by New York prosecutors in a case concerning payments made to silence 
LINGUA, Vol. 16, No. 1, Maret 2019

p ISSN: 1979 9411; e ISSN: 2442 238X

Http://lingua.pusatbahasa.or.id; Email:presslingua@gmail.com

Center of Language and Cultural Studies, Surakarta, Indonesia

Guswita, Ade Khairani. 2019. Presupposition Triggers in the Washington Post and

Lost Angeles Times Online News. Lingua (2019), 16(1): 25 36. DOI: 10.30957/lingua.v16i1.572.

women who alleged affairs with him years ago (WaPo: Des'18)

>>Trump is president, he will not be in serious jeopardy of being charged by New York prosecutors.

The example above shows that there is contrary fact which related to presuppose something in meaning Trump is president so he will not be in serious in a case concerning payments made to silence women who alleged affairs with him years ago. The journalist use trigger presupposition to imply the fact of that news made the opposing claim to be argued.

\subsubsection{Non-restrictive Clauses}

There are two major kinds of relative clauses, they are restrictive and nonrestrictive clause. But trigger a presupposition only non-restrictive clauses. A nonrestrictive clause gives additional information but does not identify the head noun. The words of non-restrictive clause are who, which, when, where, and etc. (Liang \& Liu, 2016).

Bob Corker and Jeff Flake, who have openly criticized Trump but aren't seeking reelection. (WaPo: Des'18)

>>Bob Corker and Jeff Flake have openly criticized Trump but they aren't seeking reelection.

The sentence above shows that the sentence is triggered by the use of nonrestrictive clause. The trigger who have openly criticized Trump but aren't seeking reelection refers to Bob Corker and Jeff Flake. It presupposes that the important information about the noun or noun phrase which refer to.

After collecting and analyzing the data which were found in Los Angeles Times and Washington Post about type of presupposition triggers, the writer found the result as shown in the table 1.

Table 1 shows that, there are 154 data of Los Angeles Times and 112 data of Washington Post. definite description (Extential Presuppositions Triggers) is the most dominant presupposition trigger that found in Los Angeles Times and Washington Post. In Los Angeles Times which appeared 37 times or about 24\%, and 29 times appeared in Washington Post. In Los Angeles Times, the second is non-restrictive clause that appeared 32 times or $21 \%$, followed by clef-construction that appeared 18 times or about $12 \%$, comparative constructions with 16 occurrences or about $10 \%$, adverbial clause with 12 occurrences or about $8 \%$, iteratives items with 11 occurrences or about $7 \%$, factive verbs with 8 occurrences or about $5 \%$, and both change of state verbs and counter factual conditional clause appeared 6 times or about $4 \%$, verb of judging with 4 occurrences or about $3 \%$, the number of occurrences of implicative verb and conventional items is the same, they appeared 2 times or about $1 \%$, counter factual verbs and wh-questions cannot be found in this study. 
LINGUA, Vol. 16, No. 1, Maret 2019

p ISSN: 1979 9411; e ISSN: 2442 238X

Http://lingua.pusatbahasa.or.id; Email: presslingua@gmail.com

Center of Language and Cultural Studies, Surakarta, Indonesia

Guswita, Ade Khairani. 2019. Presupposition Triggers in the Washington Post and

Lost Angeles Times Online News. Lingua (2019), 16(1): 25 36. DOI: 10.30957/lingua.v16i1.572.

Table 1. Presupposition Triggers Identified in L.A. Times and Washington Post

\begin{tabular}{|c|l|c|c|c|c|}
\hline \multirow{2}{*}{ No. } & \multirow{2}{*}{ Presupposition Triggers } & \multicolumn{2}{|c|}{ L.A Times } & \multicolumn{2}{c|}{ Washington Post } \\
\cline { 3 - 6 } & & Frequency & Percentage & Frequency & Percentage \\
\hline 1. & Definite Description & 37 & $24 \%$ & 29 & $26 \%$ \\
\hline 2. & Implicative Verb & 2 & $1 \%$ & 3 & $3 \%$ \\
\hline 3. & Factive Verb & 8 & $5 \%$ & 7 & $6 \%$ \\
\hline 4. & Change of State Verbs & 6 & $4 \%$ & 4 & $4 \%$ \\
\hline 5. & Verbs of Judging & 4 & $3 \%$ & 3 & $3 \%$ \\
\hline 6. & Counter Factual Verbs & - & 0 & - & 0 \\
\hline 7. & Conventional Items & 2 & $1 \%$ & - & 0 \\
\hline 8. & Iterative Items & 11 & $7 \%$ & 11 & $10 \%$ \\
\hline 9. & Clef Constructions & 18 & $12 \%$ & 16 & $14 \%$ \\
\hline 10. & Wh-Questions & - & 0 & 3 & $2 \%$ \\
\hline 11. & Adverbial Clause & 12 & $8 \%$ & 7 & $6 \%$ \\
\hline 12. & Comparative Constructions & 16 & $10 \%$ & 6 & $5 \%$ \\
\hline 13. & Counter Factual Conditional & & & & \\
\hline 14. & Non-Restrictive Clause & 32 & $21 \%$ & 13 & $12 \%$ \\
\hline & Total & $\mathbf{1 5 4}$ & $\mathbf{1 0 0 \%}$ & $\mathbf{1 1 2}$ & $\mathbf{1 0 0 \%}$ \\
\hline
\end{tabular}

In Washington Post, the second highest is cleft constructions which appeared 16 times or about $14 \%$, followed by non-restrictive clause with 13 occurrences or about $21 \%$, iterative item appears 11 times or about $10 \%$, counter factual conditional clause with 10 occurrences or about $9 \%$, followed by factive verb and adverbial clause that appeared 7 times or about $6 \%$, comparative constructions with 6 occurrences or about $5 \%$, change of state verbs with 4 occurrences or about $4 \%$, and the last implicative verb, verbs of judging, wh-questions that each of them appeared 3 times or about $3 \%$.

\section{CONCLUSION AND SUGGESTION}

This study concerns with the use triggers presupposition that found in Washington Post. In Los Angeles Times online new. The writer found that there are 13 types of triggers presupposition from 14 types which found in that online news. They are definite descriptions, implicative verbs, factive verbs, change of sate verbs, conventional items, iteratives items, clef constructions, Wh-questions, adverbial, comparative construction, and counter factual conditionals, and non-restrictive clauses. The most dominant type of triggers presupposition that is found in Los Angeles online news is definite descriptions which appeared 37 times or about $24 \%$ whereas there are a type of triggers presupposition that is not found in Washington Post online news, namely counter factual verbs.

In the Washington Post online news, the writer found 12 types of triggers presupposition from 14 types that proposed by Levinson (1983) and Yule (1996). The 
LINGUA, Vol. 16, No. 1, Maret 2019

p ISSN: 1979 9411; e ISSN: 2442 238X

Http://lingua.pusatbahasa.or.id; Email: presslingua@gmail.com

Center of Language and Cultural Studies, Surakarta, Indonesia

Guswita, Ade Khairani. 2019. Presupposition Triggers in the Washington Post and

Lost Angeles Times Online News. Lingua (2019), 16(1): 25 36. DOI: 10.30957/lingua.v16i1.572.

highest percentage of type of presupposition triggers in Washington Post is definite description. Counter factual verbs and conventional items aren't found in Washington Post Online. The writer concludes that the types of triggers presupposition which often appeared is extential presupposition that aim to give background information of the news or issues.

From the result of analyzing data, the difference between Los Angeles Times and Washington Post is conventional items and non-rescriptive clause. There are many non-rescriptive that appeared in LA Times than Washington Post. It indicate that journalist of L.A Times provide many additional information to the reader by using relative clause. The writer found that the occurrences of triggers presupposition is more dominant in Los Angeles Times which is there are 145 occurrences while the Washington Post just 112 occurrences. It concludes that the journalist of LA Times can more able to attract the reader with the use of trigger presupposition to make more understand about assumptions yang the journalist convey to the reader. The writer suggests that the next researcher to analyze other linguistic feature that also use pragmatic study with different object such as the talk show in the TV or internet.

\section{REFERENCES}

Borah, H. J. (2013). Presupposition: A Tool for Communication. International Journal of Innovative and Development, 2(7), 62-64.

Creswell, J.W. (2010). Research design: pendekatan kualitatif, kuantitatif, dan mixed. Yogyakarta: PT PustakaPelajar.

Grundy, P. (2000). Doing Pragmatics (Second Edition). New York: Oxford University Press.

Hamzah \& Havid, A. (2012). An Analysis of Presupposition Used in the Harry Potter and the Deathly Hallows Part 2. Journal English Language and Literature. $1(1), 1-17$

Khaleel, L. (2010). An Analysis of Presupposition Triggers in English Journalistic Text. Journal of Linguistics. 21(2), 523-551

Levinson, S. C. (1983). Pragmatics. Cambridge: Cambridge University Press.

Liang, R., \& Liu, Y. (2016). An Analysis of Presupposition Triggers in Hilary Clinton's First Campaign Speech. International Journal of English Linguistics, $6(5), 68-73$.

Sudaryanto. (2018). Metode dan Aneka Tehnik Analisis Bahasa (Pengantar Penelitian Wahana Kebudayaan secara Linguistik). Yogyakarta: Duta Wacana University Press.

Yule, G. (1996). Pragmatics. New York: Oxford University Press.

Zare, J., Abbaspour, E., and Nia, Mahji R. (2012). Presupposition Trigger -A Comparative Analysis of Broadcast News Discourse, An International Journal of Linguistics, (4)3, pp 734 -743. 